\title{
The impact of onshore wind power projects on ecological corridors and landscape connectivity in Shanxi, China
}

Article

Accepted Version

Creative Commons: Attribution-Noncommercial-No Derivative Works 4.0

Guo, X., Zhang, X., Du, S., Li, C., Siu, Y. L., Rong, Y. and Yang, H. (2020) The impact of onshore wind power projects on ecological corridors and landscape connectivity in Shanxi, China. Journal of Cleaner Production, 254. 120075. ISSN 0959-6526 doi: https://doi.org/10.1016/j.jclepro.2020.120075 Available at https://centaur.reading.ac.uk/88509/

It is advisable to refer to the publisher's version if you intend to cite from the work. See Guidance on citing.

To link to this article DOI: http://dx.doi.org/10.1016/j.jclepro.2020.120075

Publisher: Elsevier

All outputs in CentAUR are protected by Intellectual Property Rights law, including copyright law. Copyright and IPR is retained by the creators or other copyright holders. Terms and conditions for use of this material are defined in the End User Agreement.

www.reading.ac.uk/centaur 
Central Archive at the University of Reading

Reading's research outputs online 


\title{
The impact of onshore wind power projects on ecological
}

\section{corridors and landscape connectivity in Shanxi, China}

\author{
Xinya Guo a , Xingqi Zhang ${ }^{b^{*}}$, Shixun $\mathrm{Du}^{\mathrm{a}}$, Chao $\mathrm{Li}^{\mathrm{a}}$, Yim Ling Siuc ${ }^{\mathrm{c}}$, Yuejing Rong ${ }^{\mathrm{d}}$, \\ Hong Yang, , $^{*}$ \\ ${ }^{\text {a }}$ Research Center for Eco-Environment Sciences in Shanxi, Taiyuan 030000, China \\ ${ }^{\mathrm{b}}$ School of Geography and Ocean Sciences, Nanjing University, Nanjing 210023, China \\ ${ }^{\mathrm{c}}$ School of Earth \& Environment, University of Leeds, Leeds LS2 9JT, UK \\ ${ }^{\mathrm{d}}$ Research Centre for Eco-Environmental Sciences, Chinese Academy of Sciences, Beijing 100085, \\ China \\ ${ }^{\mathrm{e}}$ Collaborative Innovation Center of Atmospheric Environment and Equipment Technology, Jiangsu \\ Key Laboratory of Atmospheric Environment Monitoring and Pollution Control (AEMPC), School \\ of Environmental Science and Engineering, Nanjing University of Information Science \& \\ Technology, 219 Ningliu Road, Nanjing 210044, China \\ ${ }_{\mathrm{f}}^{\mathrm{f}}$ Department of Geography and Environmental Science, University of Reading, Reading RG6 6AB, \\ UK \\ *Corresponding authors: X. Q. Z. (zxqrh@nju.edu.cn) or H. Y. (hongyanghy@gmail.com)
}

\begin{abstract}
The wind power industry has developed rapidly in China, but the effect of wind power projects on the ecosystem is far from being clearly understood. The objective of this study is to evaluate the negative impact of wind power plants on the ecosystem. In this research, least-cost distance and least-cost path models were employed to establish potential ecological corridors based on the resistance at the site of the wind power projects-which is located in the ecological function area in Qinyuan, South Shanxi Province, China. The landscape connectivity was evaluated using a set of connectivity indices. In addition, the impact on the corridor patency, length, and the connectivity between ecological corridors were analyzed. The results showed that the wind power projects could not only significantly increase the migration resistance that hampers the formation of ecological corridors of the species at the landscape scale, but also have an obvious cutting effect on the landscape - resulting in an increase in the length of the ecological corridors and a decrease in corridor patency and landscape connectivity. There was also a positive relationship between the increase in length and the distance between the source patches. In addition, the connectivity was enhanced with the increase in distance threshold. This study evaluated the ecological impact of onshore wind power projects at the landscape level, filling the gap in research on landscape ecology, especially in the protected area with key ecological function. Meanwhile, the results are beneficial to guide the location selection for wind power projects and minimize their negative impact on the key ecological corridors.
\end{abstract}

Key words: Wind power project; Ecological corridor; Landscape connectivity; Migration resistance 


\section{Introduction}

China's economy has developed rapidly in the last four decades at the cost of the degradation of its ecology and environment (Yang et al., 2012; Yang et al., 2014a). The root cause for the ecosystem degradation is the heavy reliance on fossil fuels, particularly coal (Han et al., 2018). At present, China is still in the process of rapid urbanization and industrialization, and the demand for energy continues to grow. Maintaining the balance between rapid economic growth and environmental protection has been a big challenge for China (Yang, 2014; Yang et al., 2013). In the last decade, China has made great efforts to reverse the environmental degradation. One of the most important measures is to gradually reduce coal consumption and increase the use of renewable energy - reshaping the energy structure of China (Dai et al., 2016; Yang et al., 2016; Yang et al., 2017).

Wind power is an important form of renewable energy. With the increasing demand for energy, wind power is considered to be a promising source of renewable energy as a result of its technical maturity, low cost, flexible installation, simple operation, spatial efficiency, and minimal pollution (Hepbasli et al., 2004). In China, the wind power industry has developed rapidly due to technological progress, power guiding policies, and improved energy price mechanism (Feng et al., 2015; Sun et al., 2015). Along with the expansion of wind power industry, there are many studies on wind power technology (Khosravi et al., 2018; Zhao et al., 2015; Zhou et al., 2010), industrial development (Alexandre et al., 2012; Luo et al., 2016; Zhao et al., 2013), policy recommendations (Kang et al., 2012; Liu et al., 2010; Wolsink, 2010), and economic analyses on the investment and operation (Li et al., 2013).

However, there are potentially adverse environmental and ecological impacts of wind power projects, which should not be overlooked (Leung et al., 2013). The low frequency noise generated by rotating turbines can detrimentally impact humans and other organisms (Laratro et al., 2014; Wasala et al., 2015). The lights and shadows also visually impact the local communities (Juan et al., 2004). Additionally, the turbine blades can interfere with radio signals (Mroziński et al., 2015). Research on the ecological impact of wind power projects mainly focused on their influence on animals and plants (Escobar et al., 2015; Welcker et al., 2016; Whang et al., 2015). The impact may be direct, such as deaths caused by the rotating turbines (Peste et al., 2015; Wang et al., 2015); or indirect, such as the damage caused to foraging and breeding by habitat loss (Braunisch et al., 2015; Law et al., 2018; Madsen et al., 2008; Pescador et al., 2019). Moreover, the operation of the wind farm can affect vegetation species and biomass (Fagúndez, 2010).

In particular, it is worth noting that the construction of wind power projects changed the original landscape. The landscape pattern determines the landscape's characteristics, such as spatial heterogeneity, landscape diversity, landscape connectivity, and so on (Cook, 2002; Peng et al., 2015). Landscape process refers to the circulation and migration of internal and external material, energy, information, as well as the evolution of the landscape system (Klunder, 2004). The effects of wind power projects stem from substance retrospection above the landscape scale-which is crucial for ecological corridor construction, the maintenance of ecosystem function, and regional ecological security (Skarin et al., 2015). The fragmentation of the landscape pattern blocks the material flow, the information flow, and the species flow-affecting the landscape's ecological processes and damaging landscape (Liu et al., 2005).

The environmental impact of wind power projects can be analyzed using Geographical Information System (GIS) methods. GIS-based spatial models have been applied to effectively 
assess the impact of wind farms on animal behavior and habitats (Roscioni et al., 2013). GISassisted approaches have also been developed and applied to predict and evaluate the visual impact of wind farms (Molina-Ruiz, 2011). In addition, GIS-based approaches can be used for wind resource assessment, and can also support the decision-making process by taking into account comprehensive factors that address geological characteristics, economic cost, and environmental constraints (Haaren et al., 2011; Li, 2018; Siyal, et al., 2015). With the development of GIS technology, least-cost distance (LCD) and least-cost path (LCP) models have been increasingly applied to quantitatively research ecological corridors, landscape connectivity, ecological network construction, conservation planning, and so on (Avon et al., 2016; Barrows et al., 2011; Rabinowitz et al., 2010). Ecological corridors are land linkages which facilitate wildlife migration between green spaces, and enhance landscape connectivity to promote dispersal and other types of movement (Balbi et al., 2019; Zhu et al., 2005). The field observation has confirmed that migration corridors and habitat connectivity for some species have been disrupted owing to the construction of onshore wind power projects (Francis et al., 2018; Roscioni et al., 2014; Skarin et al., 2015). However, little has been known about their potential effect on ecological processes through the fragmentation that they cause at the landscape scale. Therefore, it is paramount to conduct a large scale quantitative ecological impact assessment of wind power projects — coupling ecological corridor with landscape connectivity—which would be necessary for the trade-off between wind power development and ecological conservation.

Shanxi Province - which is located in the eastern part of the Loess Plateau and borders on the southern part of Inner Mongolia - has abundant wind energy resources due to its geomorphological conditions - which consists of hills, deep valleys, and rugged terrain (He et al., 2014). As one of the largest energy bases in China (Cao, 2017), Shanxi Province has been aggressively pursuing the optimization of its energy structure to mitigate serious environmental pollution and ecological damage (Li et al., 2018; Wei et al., 2018; Yang et al., 2012) from its high dependence on fossil fuels. In recent years, large-scale centralized wind farms have been built in Shanxi (Wang et al., 2018). By the end of 2017, the total installed wind power capacity in Shanxi was $8.72 \times 10^{6} \mathrm{~kW}$, accounting for $11 \%$ of installed electricity generation capacity. The target for wind power development in 2020 has been set to $16 \times 10^{6} \mathrm{~kW}$, nearly double the amount in 2017 (Zhou et al., 2018). Although an environmental impact assessment is required for the wind farm project, the impact on ecological corridor and landscape connectivity is largely oversimplified or even ignored. Hence, comprehensively understanding the ecological corridor and the landscape connectivity is necessary to provide a macro-perspective ecological impact analysis at a landscape scale.

This study made the effort to fill the gap in research regarding the impact of wind power projects on ecological corridor and landscape connectivity in Shanxi Province. The main research aims of the study are: (1) to estimate the effects of wind power projects on ecological corridor by simulating the corridor construction process under multiple influence factors in the selected constructed wind power area; and (2) to explore how the landscape connectivity is affected by the wind power projects by estimating relevant connectivity indices through the use of resistance distance.

The rest of the paper is organized as follows. In Section 2, two important approachesselecting the origination of landscape process, and determining the distribution of the resistance surface with multiple factors including wind farms - were used as the basis for applying LCD and LCP methods to assess ecological corridor and landscape connectivity. In Section 3, the spatial 
distribution characteristics of the research region were presented, and the status of ecological corridor patency, corridor length, and landscape connectivity in the area before and after the construction of wind power projects were compared to assess changes in the migration routes and the landscape connectivity. In Section 4, the reasons for onshore wind power's adverse effects on landscape's ecological indicators were discussed, and some suggestions to mitigate the effects were proposed.

\section{Material and Methods}

\subsection{Study Area}

The Taiyue Mountain Wind Power Project-possessing a capacity of 250MW—is located north of Qinyuan County within Shanxi Province, China (36 $\left.51^{\prime} \mathrm{N}, 112^{\circ} 3^{\prime} \mathrm{E}\right)$ (Fig. 1). The project was proposed in 2010, and went into operation in 2014. The study area — which includes the turbines, roads, and a buffer area of $2 \mathrm{~km}$ - covers an area of $165.68 \mathrm{~km}^{2}$ and reaches a height of around 2100 $\mathrm{m}$ above sea level (asl). The average annual wind speed is $7.2 \mathrm{~m} / \mathrm{s}$ and the wind power density is $319 \mathrm{~W} / \mathrm{m}^{2}$, showing significant potential for developing wind power plants. The study area is located in a warm temperate semi-arid and semi-humid continental monsoon climate zone, with an annual mean temperature of $8.6{ }^{\circ} \mathrm{C}$ and an annual average precipitation of $656.7 \mathrm{~mm}$. The main soil type is mountain meadow soil, and the main types of vegetation are short grasses and alpine plants (Zhang, 2016).

The Taiyue Mountain Wind Power Project is the first wind power project to be built and put into production in the southeastern region of Shanxi Province. The study area is located in the ecological function area for water conservation-which is one of the most typical subalpine meadows in Shanxi Province. In addition, the wind power project lies in the experimental area of Mianshan Nature Reserve (Fig. 2). Due to its ecological importance, this area was selected to assess the ecological impact of the wind power projects.

\subsection{Data}

Landsat TM images with a resolution of $30 \mathrm{~m}$ — spanning the research period of 2005-2017were obtained from the Geospatial Data Cloud (http://www.gscloud.cn/search). These images were used to analyze the Normalized Difference Vegetation Index (NDVI). NDVI indicates the amount of green vegetation present in the pixel by measuring the difference between near-infrared - which is strongly reflected by vegetation - and the absorbed red light. Higher NDVI values denote more green vegetation in the pixel. The Landsat TM images in 2005 and 2017 were classified into different land use types. The locations of the wind turbines and the distances from the turbine were obtained from the Landsat TM images in 2017. These images were processed using the Environment for Visualizing Images (ENVI) Version 5.0 (Esri, Redlands, CA). The slope and relief were obtained using the Global Digital Elevation Model (GDEM) from the Geospatial Data Cloud (http://www.gscloud.cn/sources/?cdataid=302\&pdataid=10), with a spatial resolution of $30 \mathrm{~m}$. Daily precipitation data was provided by Shanxi Meteorological Station and calculated by using Kriging interpolation in ArcGIS 10.2 (Esri, Redlands, CA). The vegetation coverage was calculated based on the NDVI as follows:

$$
\text { Vegetation coverage }=\frac{N D V I-N D V I_{\min }}{N D V I_{\max }-N D V I_{\min }}
$$


where $N D V I_{\min }$ and $N D V I_{\max }$ represent the minimum and maximum value of NDVI, respectively.

\subsection{Methods}

The methodology of this research is schematically illustrated in Figure 3. First, to identify the starting point of ecological changes, the source patches were selected based on a variation trend analysis of the NDVI. Second, ArcGIS was applied to build a landscape resistance surface that synthesized the multiple factors affecting the landscape process in the wind farms. Third, LCD and LCP methods were used to establish the ecological corridors derived from the source patches and the landscape resistance surface. A connectivity analysis was performed using a set of connectivity indices based on the resistance of corridors. Finally, the effects of the wind power projects on the ecological corridor and the landscape connectivity were assessed based on corridor patency, corridor length, and connectivity indices.

\subsubsection{Selection of source patches}

In landscape ecology, source patches are basic units that can promote the development of the landscape ecological process (Leitao et al., 2002; Sun et al., 2018). In general, high vegetation cover areas can provide more suitable habitats - which are important for the survival of wildlife (JiménezAlfaro et al., 2016). In order to study the species migration process in the areas with good vegetation cover as indicated by the NDVI, the pixels with an increasing trend in the NDVI that linked up with each other to form a continuous area were selected as the sources, and were outlined with a closed curve.

Monadic linear regression trend analysis can simulate the changing trend of each grid, reflecting the spatiotemporal variations of the whole area. The change trend of NDVI was evaluated by using the following Monadic linear regression equation (Stow et al., 2003):

$$
\mathrm{S}=\frac{n \times \sum_{i=1}^{n}\left(i \times N D V I_{i}\right)-\left(\sum_{i=1}^{n} i\right)\left(\sum_{i=1}^{n} N D V I_{i}\right)}{n \times \sum_{i=1}^{n} i^{2}-\left(\sum_{i=1}^{n} i\right)^{2}}
$$

where $S$ is pixel's NDVI change rate; $n$ is total years, $i$ is an annual sequence; $N D V I_{i}$ is the NDVI value in the year of $i . S$ can reflect the improvement or degradation of the NDVI. $S>0$ indicates an increase in the NDVI with time. The larger the value is, the more apparent the improvement is. On the contrary, $S<0$ indicates a decrease in NDVI with time.

\subsubsection{Determination of resistance surface}

Resistance surfaces are the basis for modeling connectivity and designing conservation initiatives (Zeller et al., 2012). Different methods can be used to quantify the resistance surface. In order to avoid the risk of oversimplification, a range of indicators were used to calculate the migration resistance.

Land cover type and topography are two basic factors affecting the landscape (Diffendorfer et al., 2014). Slope and topography are the resistance factors affecting vegetation growth (Zhao et al., 2014). In addition to the direct impact on the natural environment, noise pollution and visual impact caused by the wind power projects also affect the migration of species. The low frequency noise 
and the shadows on the ground generated by the rotation of the turbines negatively impact the ecosystem (Juan et al., 2004; Laratro et al., 2014; Wasala et al., 2015). The species need to keep a certain distance away from the turbines to avoid its negative effects. Based on these, the land use type, slope, relief, vegetation coverage, the impact on vegetation, noise pollution, and visual impact were selected as factors in the assessment of the migration resistance.

Vegetation growth can be affected by climate change and human activity. Wind power projects, as a kind of human activity, has certain effects on vegetation. In order to assess the impact of wind power projects on vegetation, the impact of climate change needs to be eliminated. The residual analysis method, proposed by Evans and Geerken (2015), was used to conduct a regression analysis of the NDVI and the climate indicators for each pixel in order to obtain the prediction value of the NDVI - which can be considered as the effect of climate factors on the NDVI. Then, the vegetation influenced by human activities was calculated as the difference between the real NDVI value and the predicted NDVI value as follows:

$$
\varepsilon=N D V I_{\text {real }}-N D V I_{\text {predicted }}
$$

where $\varepsilon$ is the residual value of NDVI for each pixel. $\varepsilon>0$ indicates a positive impact caused by human activities; $\varepsilon=0$ means no impact; and $\varepsilon<0$ suggests a negative impact. $N D V I_{\text {real }}$ is the real NDVI value of the pixel, which was obtained from Landsat TM images. $N D V I_{\text {predicted }}$ is the NDVI value which was predicted by the linear regression equation between NDVI and climate indicators. Since the study area is located in a mountainous region with limited water, the main factor reflecting climate characteristics is precipitation, and the NDVI change is largely correlated with precipitation (Zhao et al., 2011).

According to the in-situ survey of the wind power projects, the blade length of the turbines is about $45 \mathrm{~m}$. Shadows of different lengths are formed on sunny days. Considering the effect of the noise, a distance of at least $200 \mathrm{~m}$ between the wind turbines and residential areas or roads would be considered safe (Wang, 2011). The attenuation effect of the turbines' noise in the air is mainly related to the propagation distance. With attenuation, the noise contribution value at $500 \mathrm{~m}$ from the turbines is less than the minimum noise level in the night (Wang, 2011). Therefore, the noise pollution and visual impact can be calculated by the distance from the turbine.

For a landscape factor, the resistance value was determined according to the different degrees of impact on migration. Table 1 summarizes the relative resistance values of different landscape factors. Within the resistance value range of 1-100, the species move freely when the resistance value is close to 1 . However, they cannot move when the value is close to 100 . The resistance value of the forest was the smallest, followed by grassland, farmland, and construction land. The larger the slope and the relief are, the greater the resistance value is.

The comprehensive analysis was performed to synthesize the spatial layers of each factor by running ArcGIS. Each resistance factor was classified using the reclassify tool and the corresponding resistance value was assigned to each landscape unit for each factor layer. The resistance surface was determined by overlaying these factor layers together.

\subsubsection{Establishment of ecological corridors by Least-cost distance and Least-cost path}

The relationship between the landscape pattern and the ecological process is the core of landscape ecology (Fu et al., 2011). The landscape pattern and the spatial combination 
characteristics of different landscape elements are relatively static in a given period of time, but the real ecological process can be dynamic during the same period. Source-sink landscape theory breaks through this limitation in the traditional sense-making the landscape pattern dynamic and reflecting both the influence of the pattern on the process and the effect of the process on the pattern (Chen et al., 2003; Chen et al., 2008). The approaches for regulating the ecological process were analyzed based on the spatial balance of the "source" landscape. The extension of species to the surroundings is a process of competitive control of land use, which must be achieved by overcoming the resistance, so the resistance surface can reflect the spatial trend of species migration. With the advantage of evaluating the landscape spatial patterns by analyzing the effects of different landscape types on the target species, the LCD and the LCP have been applied to evaluate the impact of different land use types on the ecological flow (Balbi et al., 2019; Chetkiewicz et al., 2009). Similarly, the LCD and the LCP models were used to establish ecological corridors based on the resistance surface in this study (Walker et al., 1997).

LCD is the accumulated cost distance of the most likely route where an individual would take to move between two habitat patches (Walker et al., 1997). Since many factors affect species migration, a range of distances rather than only one is used, causing variation in species dispersal distances (Adriaensen et al., 2003). In the LCD model, a single path of least resistance between two nodes is identified based on the resistance surface (Adriaensen et al., 2003). All paths between two habitat patches are used to calculate resistance distance, which represents the effective distance separating the two habitat patches for a species (Ayon et al., 2016). Resistance distance has been widely used to evaluate the functional landscape connectivity between patches (Avon et al., 2016; Rabinowitz et al. 2010; Richard et al., 2010). In addition, LCP is the single path for a species to move between two source patches.

Both the LCD and the LCP methods were performed in ArcGIS 10.2. In the LCD model, cumulative cost from each pixel to the nearest source was obtained by inputting the previously derived source patches and resistance surface. As a further calculation based on the LCD, the LCP identified a singular least cost path connecting every two source patches based on cumulative cost. These paths were the potentially ecological corridors.

\subsubsection{Assessment of landscape connectivity}

The connectivity of each habitat patch in the network was assessed using a measure of the relative change in the integral index of connectivity (IIC) and probability of connectivity (PC) (Pascual-Hortal and Saura 2006; Saura and Pascual-Hortal 2007) following the equations:

$$
\begin{gathered}
\mathrm{IIC}=\frac{\sum_{i=1}^{n} \sum_{j=1}^{n} a_{i} \times a_{j}}{1+n l_{i j}} \\
A_{L}^{2} \\
\mathrm{PC}=\frac{\sum_{i=1}^{n} \sum_{j=1}^{n} a_{i} \times a_{j} \times P_{i j}}{A_{L}^{2}}
\end{gathered}
$$

where $a_{i}$ and $a_{j}$ are the area of each habitat patch; $n l_{i j}$ is the number of links in the shortest path (topological distance) between patches $i$ and $j$; $A_{L}$ is the total area; and $P_{i j}$ is the maximum product probability of all paths between patches $i$ and $j$. If patches $i$ and $j$ are close enough, the maximum probability path will simply be the step between nodes $i$ and $j$. If patches $i$ and $j$ are more distant, the maximum probability path will probably be composed of several steps through intermediate 
stepping stone patches.

The impact of the wind power projects on landscape connectivity of core patches was evaluated by using the equivalent connected area (ECA) - which includes the equivalent connected area of integral connectivity (EC(IIC)) and the equivalent connected area of probability connectivity (EC(PC))—using Conefor 2.6 (Saura and Torne, 2009).

\section{Results}

\subsection{Spatial patterns of the NDVI variation trend and the resistance surface}

Figure 4 and Table 2 show the statistical characteristics of the NDVI changing trends during the 2005-2017 period. The variation trends were divided into serious degradation $(S \leqslant-0.01)$, degradation $(-0.01<S \leqslant-0.005)$, unchanged $(-0.005<S<0.005)$, increase $(0.005<S<0.01)$, and significant increase ( $S>0.01$ ), according to their $S$ values. Approximately $59.35 \%$ of the NDVI values remained basically unchanged, $26.69 \%$ of the NDVI showed an increasing trend, and $13.97 \%$ of the NDVI showed a decreasing trend.

The NDVI values in the northern part of the study area were less affected by human activities and illustrated a period of growth through their increasing trend. Despite the effect of human activities and climate change, the NDVI of shrub and grassland in the central and southern parts of the study remained largely unchanged during the study period.

The NDVI variation trend was related to the change in the type of land use. Table 3 and Figure 5 show the different land use categories with and without the wind power projects. Forestsincluding the deciduous broad-leaved forest, the evergreen needle forest, and the deciduous broadleaved shrub - accounted for $77.13 \%$ of the whole area in 2017. Grassland, which includes grass and meadow, accounted for $14.10 \%$. Farmland, residential land, and industrial land areas accounted for $3.04 \%, 0.09 \%$ and $5.64 \%$ respectively. Compared to the period before the construction of the wind power projects in 2005, the area of the main patterns of land use in the source patches-the evergreen needle forest and the deciduous broad-leaved forest - increased in 2017. This indicates that the ecosystem of the source patches was less impacted by the wind power projects.

Figure 6 shows the spatial distribution of the different landscape resistances with and without the wind power projects. The resistance distribution is continuous, and low resistance dominated in the study area without wind power projects. When the wind power projects were built, the resistance values were obviously stratified, and the largest resistance values appeared in area of the wind power projects.

\subsection{Effects of wind power projects on the ecological corridor and the landscape connectivity}

Based on the NDVI evaluation results, seven sources were identified in the study area. Considering the ecological corridors with the least cumulative resistance, potential ecological corridors connecting every two source patches with and without the wind power projects were created based on the LCD values (Fig. 7). There were seven sources in different locations throughout the study area. In order to maintain landscape connectivity and ensure that species can move smoothly between sources, every two source patches were connected by an ecological corridor. The overlap of ecological corridors with and without the wind power projects was small, indicating that the construction of wind power projects had changed the ecological corridors. 


\subsubsection{Effects on corridor patency}

Figure 8 shows the before and after comparison of the resistance increment resulting from the wind power projects. The construction of the wind power projects reduced the corridor patency between the source patches, which is reflected in the increase in the LCD values. Although the LCD values of one corridor decreased, this corridor does not go through the region of the wind power projects - indicating minimal impact by the wind power projects on this corridor. The average, minimum and maximum of the LCD increased to $1019.66,71.35$, and 3557.43 respectively. The high resistance corridors generally crossed over the wind power projects, resulting in an enhanced reduction effect on the corridor patency.

\subsubsection{Effects on corridor length}

Figure 9 shows the comparison of the corridor length increment between before and after the wind power projects were built. The wind power projects lengthened most of the corridors, thus increasing the migration distance. The length of one corridor decreased, while the lengths of others increased by different levels - with the average increase being $95 \mathrm{~km}$. The increase was related to the distance between the source patches. The farther the distance was, the larger the increase was. The distance between the source patches of no. 1 and no.7 was the largest, which made the length of the corridors increase by $119.460 \mathrm{~km}$. A thorough change in the route between source patches of no. 3 and no.5 led to a 6.5 -fold increase in the corridor length.

The relationships between the rate of reduction of the corridor patency and the rate of increase of the corridor length were expressed as $P=0.268 L-24.804$ and $L=3.499 P+125.726$, where $P$ is the reduction rate (\%) of the corridor patency and $L$ is the increase rate (\%) of the corridor length. The determination coefficient $\left(\mathrm{R}^{2}\right)$ is 0.937 , indicating a well-fitted linear relationship.

\subsubsection{Effects on landscape connectivity}

Habitat network models were used to calculate a set of connectivity indices-including EC(IIC) and $\mathrm{EC}(\mathrm{PC})$ - using Conefor 2.6. The patch connectivity is related to the scales of different ecological processes, and the calculation of the connectivity index needs to specify the distance threshold for the patch connectivity (Ramirez-Reyes et al., 2016). When the resistance distance exceeds the distance threshold, the two patches are not related. Otherwise, they are related. According to the real LCD values, 1000, 3000, and 5000 were set as the distance thresholdsrepresenting weak, medium, and strong migration ability respectively (Table 4). Comparing the before and after values indicates that the construction of the wind power projects weakened the ecological processes of different migration abilities. The reduction rates of EC(IIC) under different distance thresholds were $25.09 \%, 0.85 \%$, and 0 respectively. The reduction rates of EC(PC) under different distance thresholds were $11.06 \%, 3.91 \%$, and $2.35 \%$ respectively. The value of the connectivity index increased gradually along with the growth of the distance threshold, indicating that the larger the scale of the ecological process was, the higher the connectivity of the same landscape was. 


\section{Discussions}

\subsection{NDVI variation trend and resistance surface characteristics}

The LCD model was used to identify the ecological corridors in this study. In the application of a concrete model, the source patches and the resistance surface should be considered. The source patches were identified based on the NDVI variation trend. Potential ecological corridors connecting the source patches were calculated based on the resistance surface value.

Wind power projects not only include large sized turbines (point projects), but also additional associated infrastructure required to support an array of turbines, such as roads and electrical transmission lines (line projects). Although the turbine footing occupies marginal land, there are numerous turbines and they span a wide range of area. The study area mainly consisted of highquality land conducive to the growth of forest and meadow, and the construction of the wind power projects unavoidably destroyed the original vegetation. Meanwhile, the construction of turbines and roads caused various levels of interference to the landscape structure, wildlife movement, and the land use change in the surrounding areas (Fu et al., 2010; Loro et al., 2015; Obermeye et al., 2011; Shi et al., 2018). The range of interference may be further expanded with large scale development. As shown in Table 1, the resistance value was negatively correlated with the vegetation coverage and the distance from the turbine, so the construction of the wind power projects contributed significantly to the increased resistance.

\subsection{Effects of wind power projects on the ecological corridor and landscape connectivity}

Ecological corridors can be the habitat of wildlife, and they can act as a channel, source, sink, obstruction, and filter for biological movement—serving many functions such as biodiversity conservation, contamination filtration, erosion prevention, and flood control (Forman, 1995; Zhu et al., 2005). As an industrial zone with fully equipped infrastructure to support specific targeted industries, the wind power projects are not conducive for the formation of ecological corridors due to the lack of ecological function. In addition, the wind power projects - as pointed and linear landscape units - have an obvious cutting effect on the landscape (Kuvlesky et al., 2007; Obermeye et al., 2011). It cut the entire landscape into isolated patches, causing an extensive fragmentation of the landscape and the isolation of wildlife. Therefore, the wind power projects negatively impact the ecological corridor patency, the ecological corridor length and the landscape connectivitythrough their construction of turbines and their development of infrastructure such as roads.

On the one hand, the construction of the wind power projects altered the direction of the corridors between the source patches in the landscape - which hindered the migration and diffusion of species (Kuvlesky et al., 2007) — leading to the reduction in corridor patency. On the other hand, the construction of the wind power projects also changed the landscape structure and weakened the species exchange among the patches. A species can move a larger geographical distance through permeable landscapes than through high resistance landscapes (Avon and Berges, 2016). When the species has to migrate over high resistance areas, the corridor length increases at the same time. Our results confirm the significant relationship between the rate of increase of the corridor length and rate of reduction of the corridor patency. The corridor length increased greatly due to corridor change, leading to an increase in the resistance. Even though the distance in the source patches between no. 1 and no. 2 decreased, the resistance still increased. Increased resistance means that the ecological corridors with rich biodiversity and important ecological functions will play less 
important roles. Clearly, the negative impact of wind power projects should not be ignored. Wildlife are sensitive to human infrastructure and activity, and they have to adjust their migration routes to avoid the low frequency noise and the shadows on the ground generated by the rotation of the turbines (Cabrera-Cruz et al., 2016; Harrison et al., 2017).

In addition, studies found that the landscape configuration became fragmented and the connectivity of the natural landscape declined along with wind energy development (Kuvlesky et al., 2007; Obermeye et al., 2011). The wind power projects in the study area include 164 turbines and 80 connecting roads. The construction has an obvious cutting effect on the landscape, causing landscape fragmentation and a decline in connectivity. Fragmentation is detrimental to both the integrity of the ecological systems and the long-term viability of associated wildlife, and may magnify the deleterious effects on species and ecosystems by limiting the species' ability to adapt or migrate (Ewers et al., 2006). Therefore, the protection of the current ecological corridors and the construction of new ones in appropriate locations should be prioritized.

\subsection{Comparison between the current study with previous results}

This study focuses on ecological corridors and landscape connectivity to better reflect the landscape pattern and the landscape ecological structure. In view of the ecological impact of onshore wind power projects, there are some differences in research objectives, methods, and results between this study and previous studies (Table 5). Unlike many previous studies-which focused on particular species (especially birds) - this study instead focused primarily on the landscape ecology to determine the potential ecological corridor - which provide the paths for wildlife migration and plays an important role in connecting the isolated and dispersed ecosystem (Zhu et al., 2005). Our purpose was to quantitatively evaluate the ecological impact of the wind power projects on the ecological corridor and the landscape connectivity. Meanwhile, with the GIS technology, this study took into account the specific elements of the wind power projects to accurately assess their impact on the ecosystem. Previous studies showed that the construction of wind power projects altered the migration corridors (Cabrera-Cruz et al., 2016; Harrison et al., 2017; Pocewicz et al., 2013; Skarin et al., 2015) — reinforcing our results which depicted changes in the ecological corridors with respect to wildlife migration.

\subsection{Implication and application of the results}

Landscape planning for species of concern requires detailed knowledge of the amount and the quality of habitats as well as the connectivity or spatial configuration of habitats (Fahrig, 2001). The construction of an ecological corridor is beneficial for the conservation of biodiversity. Landscape connectivity is an important factor to consider during the decision-making process. The wind power projects can be routed optimally so that the disturbance can be minimized.

The construction of projects at different stages can have various effects on ecosystems (Hazem et al., 2019; Lin, 2018). In order to reduce the negative impact of a wind power project on the landscape ecology, an ecological impact assessment should be carried out strictly before the construction, and ecological restoration should be carried out properly after construction. It is necessary to scientifically plan and identify the optimal location for wind power projects. A quantitative assessment of the impact of the wind power projects on the ecological corridor and the landscape connectivity is the foundation of scientific planning in ecologically sensitive areas. 
Figures 8 and 9 show a comparison of the impact on the ecological corridor with and without the wind power projects, and Table 4 shows the comparison of the impact on landscape connectivitywhich can be used to evaluate the ecological impact of the proposed wind power projects before their construction. Traditionally, the location selection of the wind power projects focuses on local wind resources, but its negative effects on ecosystems should not be ignored. According to the results in Figures 7, 8, and 9, and Table 4, in order to minimize the impact of the wind power projects on the ecological system, the following steps need to be undertaken. First, attention must be given to the ecological corridors that suffer significant changes due to wind farm construction. Second, the wind farms that affect these corridors should be identified. Lastly, suitable locations for the wind farms should be selected based on the degree of their impact on the ecosystem. In addition, ecological restoration is mainly to improve the ecosystem service functions. In our study area, the main aim of ecological restoration is to improve water conservation and maintain biodiversity. Around the constructed area of the wind power projects, local dominant species of dwarf grass and alpine plants — such as purple fescue, lanceola, and others — should be planted.

This study analyzed the ecological impact of the wind power projects at the landscape level in Shanxi Province, filling the gap in research on the same. In addition, this study focused on the preconstruction and the operational phase of the wind farms, thus beneficially guiding the selection of locations for future wind power projects by avoiding the key ecological corridors in the area. Reducing carbon emissions by replacing fossil fuels with renewable energy has received increasing attention in most countries. In the meantime, measures are still needed to mitigate the environmental and ecological impacts caused by the development of renewable energy (Yang et al., 2014b).

\subsection{Limitation and future study}

Similar to many existing studies, this study also has its limitations. The LCD method has been widely used for landscape ecology evaluation (Avon et al. 2016; Chen et al. 2017), but it is difficult to accurately set the resistance values. Due to a lack of observational data, the simulation results were not able to be calibrated-possibly incorporating a certain level of bias within the results. However, the performance evaluation is based on the comparative data, and is not informed by direct simulations of the observed results. For this reason, the impact of bias on the calculated results due to uncertainty regarding the resistance values is minor (Shi et al., 2018). In addition, this study did not analyze the obstructed situation of different species such as flying birds, large animals, and small animals - which could affect the pertinence of the calculation results. Even so, the ecological influence of the wind power projects revealed in this study can facilitate sustainable wind power development in the future (Francis et al., 2018; Skarin et al., 2015). In future studies, field observations of the migration of different species can be applied to further improve the simulation results.

\section{Conclusions}

This study evaluated the impact of onshore wind power projects on the ecological corridors and the landscape connectivity in the Taiyue Mountain Wind Power Project in Qinyuan, Shanxi, China.

The results showed that the wind power project not only significantly increased the resistance to the formation of ecological corridors at the landscape level, but also had an obvious cutting effect 
on the landscape - resulting in an increase in the length of the ecological corridors and a decrease in the corridor patency and the landscape connectivity. The resistance distribution determines the construction of corridors that are beneficial for species migration. When the wind power projects were built, the resistance value was obviously stratified, and the largest resistance value appeared in the area of wind power projects. The construction of the wind power projects reduced the corridor patency between the source patches, which was reflected in the increase in the migration resistance. The average increased value and rate were 1019.66 and $148.63 \%$ respectively. The construction of the wind power projects altered the direction and length of the corridor between the source patches, which hindered the migration and diffusion of species. The wind power projects caused most corridors to grow in length, and the average length increased by $95 \mathrm{~km}$. The further the distance was, the larger the increased value was. The relationships between the rate of reduction in corridor patency and the rate of increase in corridor length were expressed as $P=0.268 L-24.804$ and $L=3.499$ $P+125.726$ ( $P$ is the rate of reduction (\%) in corridor patency and $L$ is the rate of increase (\%) in corridor length). The construction of the wind power projects weakened the landscape connectivity, which was illustrated by the reduction of the connectivity indices. In addition, the larger the scale of the ecological process was, the higher the connectivity of the same landscape was. When resistance thresholds were $1000 \mathrm{~m}, 3000 \mathrm{~m}$, and $5000 \mathrm{~m}$, the reduction rates of $\mathrm{EC}$ (IIC) were $25.09 \%$, $0.85 \%$, and 0 respectively; while the reduction rates of $\mathrm{EC}(\mathrm{PC})$ were $11.06 \%, 3.91 \%$, and $2.35 \%$ respectively.

Our results indicate the ecological impact of wind power plants, and therefore it is crucial for strict ecological impact assessments to be conducted before the construction of wind power plants. Afterwards, its ecological damage should be minimized by undertaking comprehensive ecological restoration.

\section{Acknowledgements}

We thank Geospatial Data Cloud, Shanxi Meteorological Station for the NDVI, the DEM data and the meteorological data. This work was supported by the Natural Science Foundation of Shanxi Province (2014012003) and open funded by the Jiangsu Key Laboratory of Atmospheric Environment Monitoring and Pollution Control (KHK1806) - a project funded by the Priority Academic Program Development of Jiangsu Higher Education Institutions (PAPD).

\section{References}

Adriaensen, F., Chardon, J. P., De Blust, G., Swinnen, E., Villalba, S., Gulinck, H., Matthysen, E., 2003. The application of 'least-cost' modeling as a functional landscape model. Landscape and Urban Planning 64, 233-247. doi: 10.1016/S0169-2046(02)00242-6

Alexandre Château, F., Chang, Y.C., Chen, H., Ko, T. T., 2012. Building a stakeholder's vision of an offshore wind-farm project: A group modeling approach. Science of the Total Environment 420, 43-53. doi: 10.1016/j.scitotenv.2012.01.031

Avon, C., Berges, L., 2016. Prioritization of habitat patches for landscape connectivity conservation differs between least-cost and resistance distances. Landscape Ecology 31, 1551-1565. doi:10.1007/s10980-015-0336-8

Balbi, M., Petit, E. J., Croci, S., Nabucet, J., Georges, R., Madec, L., Ernoult, A., 2019. Ecological relevance of least cost path analysis: An easy implementation method for landscape urban 
planning. Journal of Environmental Management 244, 61-68.

doi: 10.1016/j.jenvman.2019.04.124

Barrows, C. W., Fleming, K. D., Allen, M. F., 2011. Identifying Habitat Linkages to Maintain Connectivity for Corridor Dwellers in a Fragmented Landscape. The Journal of Wildlife Management 75, 682-691. doi: 10.1002/jwmg.138

Braunischa, V., Coppesa, J., Bächlea, S., Suchant, R., 2015. Underpinning the precautionary principle with evidence: A spatial concept for guiding wind power development in endangered species' habitats. Journal for Nature Conservation 24, 31-40. doi: 10.1016/j.jnc.2015.01.003

Cabrera-Cruz, S. A., Villegas-Patraca, R., 2016. Response of migrating raptors to an increasing number of wind farms. Journal of Applied Ecology, 1-9. doi: 10.1111/1365-2664.12673

Cao, X., 2017. Policy and regulatory responses to coalmine closure and coal resources consolidation for sustainability in Shanxi, China. Journal of Cleaner Production 145, 199-208. doi: 10.1016/j.jclepro.2017.01.050

Chen, C. D., Wu, S.J., Meurk, C. D., lv, M. Q., Wen, Z. f., Jiang, Y., Chen., J. L., 2015. Effects of changing cost surface values on landscape connectivity simulation. Acta Ecologica Sinica 35, 7367-7375. doi: 10.5846/stxb201404010611

Chen, C., Meurk, C. D., Jia, Z. Y., Lv, M. Q., Wu, S. J., Jia, J. S., 2017. Incorporating landscape connectivity into household pond configuration in a hilly agricultural landscape. Landscape and Ecological Engineering 13, 189-204. doi: 10.1007/s11355-016-0317-3

Chen, L. D., Fu, B. J., Xu, J. Y., Gong, J., 2003. Location-weighted landscape contrast index: a scale independent approach for landscape pattern evaluation based on "Source-Sink" ecological processes. Acta Ecologica Sinica 23, 2406-2413. doi: 10.3321/j.issn:1000-0933.2003.11.025

Chen, L. D., Fu, B. J., Zhao, W. W., 2008. Source-sink landscape theory and its ecological significance. Frontiers of Biology in China 3, 131-136. doi: 10.1007/s11515-008-0026-x

Chetkiewicz, C. L. B, Boyce, M. S., 2009. Use of resource selection functions to identify conservation corridors. Journal of Applied Ecology 46, 1036-1047. doi: 10.1111/j.1365-2664.2009.01686.x

Cook, E. A., 2002. Landscape structure indices for assessing urban ecological networks. Landscape and Urban Planning 58, 269-280. doi: 10.1016/s0169-2046(01)00226-2

Dai, H. C., Xie, X. X., Xie, Y., Liu, J., Masui, T., 2016. Green growth: The economic impacts of large-scale renewable energy development in China. Applied Energy 162: 435-449. doi: 10.1016/j.apenergy.2015.10.049

Diffendorfer, J. E., Compton, R. W., Magar, V., 2014. Land Cover and Topography Affect the Land Transformation Caused by Wind Facilities. PLoS ONE 9, e88914. doi: 10.1371/journal.pone.0088914

Escobar, L. E., Juarez, C., Medina-Vogel, G., Gonzalez, C. M., 2015. First Report on Bat Mortalities on Wind Farms in Chile. GAYANA 79, 11-17. doi: 10.4067/S0717-65382015000100003

Evans, J., Geerken, R., 2004. Discrimination between climate and human-induced dryland degradation. Journal of Arid Environments 57, 535-554. doi: 10.1016/S0140-1963(03)00121-6

Ewers, R. M., Didham, R. K., 2006. Confounding factors in the detection of species responses to 
Fagúndez, J., 2008. Effects of wind farm construction and operation on mire and wet heath vegetation in the Monte Maior SCI, north-west Spain. Mires and Peat 4, 1-12. In: http://www.mires-and-peat.net/, ISSN 1819-754X.

Fahrig, L., 2001. How much habitat is enough? Biological Conservation 100, 65-74. doi: 10.1016/S0006-3207(00)00208-1

Feng, Y., Lin, H., Ho, S. L., Yan, J., Dong, J. N., Fang, S. H., 2015. Overview of wind power generation in China: Status and development. Renewable and Sustainable Energy Reviews 50, 847-858. doi: 10.1016/j.rser.2015.05.005

Forman, R. T. T., 1995. Some general principles of landscape and regional ecology. Landscape Ecology 10, 133-142. doi: 10.1007/BF00133027

Francis, O., Safi, Kamran., Aryal, Jagannath., 2018. Predicting Migratory Corridors of White Storks, Ciconia ciconia, to Enhance Sustainable Wind Energy Planning: A Data-Driven Agent-Based Model. Sustainability 10, 1470. doi: 10.3390/su10051470

Fu, B. J., Chen, L. D., Ma, K. M., Wang, Y. L., 2011. The principle and application of landscape ecology. Beijing: Science Press.

Fu, W., Liu, S., Degloria, S. D., Dong, S. K., Beazleyc, R., 2010. Characterizing the "fragmentationbarrier" effect of road networks on landscape connectivity: A case study in Xishuangbanna, Southwest China. Landscape and Urban Planning 95, 122-129. doi: 10.1016/j.landurbplan.2009.12.009

Haaren, R. V., Fthenakis, V., 2011. GIS-based wind farm site selection using spatial multi-criteria analysis (SMCA): Evaluating the case for New York State. Renewable and Sustainable Energy Reviews 15, 3332-3340. doi: 10.1016/j.rser.2011.04.010

Han, S., Chen, H., Long, R., Cui, X., 2018. Peak coal in China: A literature review. Resources, Conservation and Recycling 129, 293-306. doi: 10.1016/j.resconrec.2016.08.012

Harrison, A. L., Petkov, N., Mitev, D., Popgeorgiev, G., GoveGeoff, B., Hilton, M., 2017. Scaledependent habitat selection by wintering geese: implications for landscape management. Biodiversity and Conservation 27, 167-188. doi: 10.1007/s10531-017-1427-4

Hazem, R. T., Breesam, H. K., 2019. Development of Possible Solution to Overcome Factors Influence on Sustainable Construction Process. Civil Engineering Journal 5, 1506-1517. doi: 10.28991/cej-2019-03091348

He, G., Kammen, D. M., 2014. Where, when and how much wind is available? A provincial-scale wind resource assessment for China. Energy Policy 74, 116-122. doi: 10.1016/j.enpol.2014.07.003

Hepbasli, A., Ozgener, O., 2004. A review on the development of wind energy in Turkey. Renewable and Sustainable Energy Reviews 8, 257-276. doi: 10.1016/j.rser.2003.10.006

Jiménez-Alfaro, Borja., Chytrý, M., Mucina, L., Grace, J. B., Rejmánek, M., 2016. Disentangling vegetation diversity from climate-energy and habitat heterogeneity for explaining animal geographic patterns. Ecology and Evolution 6, 1515-1526. doi: 10.1002/ece3.1972

Juan, P. H., Joaquin, F., Jorge, L. P., 2004. Spanish method of visual impact evaluation in wind farm. Renewable and Sustainable Energy Reviews 8, 483-491. doi: 10.1016/j.rser.2003.12.009

Kang, J. j., Yuan, J. H., Hu, Z. G., Xu, Y., 2012. Review on wind power development and relevant policies in China during the 11th Five-Year-Plan period. Renewable and Sustainable Energy 
Reviews 16, 1907-1915. doi: 10.1016/j.rser.2012.01.031

Khosravi, S., Zamanifar, M., Derakhshan-Barjoei., P., 2018. Analysis of Bifurcations in a Wind Turbine System Based on DFIG. Emerging Science Journal 2, 39-52. doi: 10.28991/esj-2018-01126

Klunder, G., 2004. The search for the most eco-efficient strategies for sustainable housing construction; Dutch lessons. Journal of Housing and the Built Environment 19, 111-126. doi: 10.1023/b:joho.0000017709.65252.e4

Kuvlesky, W. P., Brennan, L. A., Morrison, M. L., Boydston, K. K., Ballard, B. M., Bryant, F. C., 2007. Wind energy development and wildlife conservation: Challenges and opportunities. The Journal of Wildlife Management 71, 2487-2498. doi: 10.2193/2007-248

Laratro, A., Arjomandi, M., Kelso, R., Cazzolato, B., 2014. A discussion of wind turbine interaction and stall contributions to wind arm noise. Journal of Wind Engineering and Industrial Aerodynamics 127, 1-10. doi: 10.1016/j.jweia.2014.01.007

Law, P. R., Fuller, M.,2018. Evaluating anthropogenic landscape alterations as wildlife hazards, with wind farms as an example. Ecological Indicators 94, 380-385. doi: 10.1016/j.ecolind.2018.06.061

Leitao, A.B., Ahern, J., 2002. Applying landscape ecological concepts and metrics in sustainable landscape planning. Landscape and Urban Planning 59, 65-93. doi: 10.1016/S0169-2046(02)00005-1

Leung, D., Yang, Y., 2012. Wind energy development and its environmental impact: A review. Renewable and Sustainable Energy Reviews 16, 1031-1039. doi: 10.1016/j.rser.2011.09.024

Li, C. B., Lu, G. S., Wu, S., 2013. The investment risk analysis of wind power project in China. Renewable Energy 50, 481-487. doi: 10.1016/j.renene.2012.07.007

Li, L., Lei, Y., S, Wu., He, C., Yan, D., 2018. Study on the coordinated development of economy, environment and resource in coal-based areas in Shanxi Province in China: Based on the multiobjective optimization model. Resources Policy 55, 80-86. doi: 10.1016/j.resourpol.2017.10.017

Li, Z. D., 2018. Study of site suitability assessment of regional wind resources development based on multi-criteria decision. Clean Technologies and Environmental Policy 20, 1147-1166. doi: 10.1007/s10098-018-1538-y

Lin, F., 2018. Construction Network Ventilation System for Underground LPG Storage Cavern. Civil Engineering Journal 4, 1521-1541. doi: 10.28991/cej-0309192

Liu, J. F., Xiao, W. F., Jiang, Z. P., Xia, F., Li, X. Y., 2005. A study on the influence of landscape fragmentation on biodiversity. Forest Research 18, 222-226. doi: 10.1360/biodiv.050121

Liu, Y. Q., Kokko, A., 2010. Wind power in China: Policy and development challenges. Energy Policy 38, 5520-5529. doi: 10.1016/j.enpol.2010.04.050

Loro, M., Ortega, E., Arce, R. M., Geneletti, D., 2015. Ecological connectivity analysis to reduce the barrier effect of roads. An innovative graph-theory approach to define wildlife corridors with multiple paths and without bottlenecks. Landscape and Urban Planning 139, 149-162. doi: 10.1016/j.landurbplan.2015.03.006

Luo, G. L., Li, Y. L., Tang, W. J., Wei, X., 2016. Wind curtailment of China's wind power operation: Evolution, causes and solutions. Renewable and Sustainable Energy Reviews 53, 1190-1201. doi: 10.1016/j.rser.2015.09.075

Madsen, J., Boertmann, D., 2008. Animal behavioral adaptation to changing landscapes: spring- 
staging geese habituate to wind farms. Landscape Ecology 23, 1007-1011. doi: 10.1007/s10980-008-9269-9

Mojica, E. K., Watts, B. D., Turrin, C. L., 2016. Utilization Probability Map for Migrating Bald Eagles in Northeastern North America: A Tool for Siting Wind Energy Facilities and Other Flight Hazards. Plos One, 11, e0157807. doi: 10.1371/journal.pone.0157807

Molina-Ruiz, J., Martínez-Sánchez, M. J., Pérez-Sirvent, C., Tudela-Serrano, M. L., Lorenzo, M. L. G., 2011. Developing and applying a GIS-assisted approach to evaluate visual impact in wind farms. Renewable Energy 36, 1125-1132. doi: 10.1016/j.renene.2010.08.041

Mroziński, A., Piasecka, I., 2015. Selected aspects of building, operation and environmental impact of offshore wind power electric plants. Polish Maritime Research 22, 86-92. doi: 10.1515/pomr-2015-0021

Pascual-Hortal, L., Saura, S., 2006. Comparison and development of new graph-based landscape connectivity indices: towards the prioritization of habitat patches and corridors for conservation. Landscape Ecology 21, 959-967. doi: 10.1007/s10980-006-0013-Z

Pocewicz, A., Estes-Zumpf, W. A., Andersen, M. D., Copeland, H. E., Keinath, D. A., Griscom, H. R., 2013. Modeling the Distribution of Migratory Bird Stopovers to Inform Landscape-Scale Siting of Wind Development. PLOS ONE 8, e75363. doi: 10.1371/journal.pone.0075363

Peng, J., Liu, Y. X., Wu, J. S., Lv, H. L., Hu, X. X., 2015. Linking ecosystem services and landscape patterns to assess urban ecosystem health: A case study in Shenzhen City, China. Landscape and Urban Planning 143, 56-68. doi: 10.1016/j.landurbplan.2015.06.007

Pescador, M., Ramírez, J. I. G., Peris, S. J., 2019. Effectiveness of a mitigation measure for the lesser kestrel (Falco naumanni) in wind farms in Spain. Journal of Environmental Management 231, 919-925. doi: 10.1016/j.jenvman.2018.10.094

Peste, F., Paul, A., da Silva, L. P., 2015. How to mitigate impacts of wind farms on bats? A review of potential conservation measures in the European context. Environmental Impact Assessment Review 51, 10-22. doi: 10.1016/j.eiar.2014.11.001

Obermeye, B., Manes, R., Kiesecker, J., Fargione, J., Sochi, K., 2011. Development by Design: Mitigating Wind Development's Impacts on Wildlife in Kansas. PLoS ONE 6, e26698. doi: 10.1371/journal.pone.0026698

Rabinowitz, A., Zeller, K. A., 2010. A range-wide model of landscape connectivity and conservation for the jaguar, Panthera onca. Biological Conservation 143, 939-945. doi: 10.1016/j.biocon.2010.01.002

Ramirez-Reyes, C., Bateman B. L., Radeloff V. C., 2016. Effects of habitat suitability and minimum patch size thresholds on the assessment of landscape connectivity for jaguars in the Sierra Gorda, Mexico. Biological Conservation 204, 296-305.

doi: 10.1016/j.biocon.2016.10.020

Richard, Y., Armstrong, D. P., 2010. Cost distance modelling of landscape connectivity and gapcrossing ability using radio-tracking data. Journal of Applied Ecology 47, 603-610. doi: 10.1111/j.1365-2664.2010.01806.x

Roscioni, F., Rebelo, H., Russo, D., Carranza, M. L., Febbraro, M. D., Loy, A., 2014. A modelling approach to infer the effects of wind farms on landscape connectivity for bats. Landscape Ecology 29,891-903. doi: 10.1007/s10980-014-0030-2

Saura, S., Pascual-Hortal, L., 2007. A new habitat availability index to integrate connectivity in 
landscape conservation planning: comparison with existing indices and application to a case study. Landscape and Urban Planning 83, 91-103. doi: 10.1016/j.landurbplan.2007.03.005

Saura, S., Torne, J., 2009. Conefor Sensinode 2.2: A software package for quantifying the importance of habitat patches for landscape connectivity. Environmental Modelling \& Software 24, 135-139. doi: 10.1016/j.envsoft.2008.05.005

Shi, H., Shi, T., Yang, Z., Wang, Z., Han, F., Wang, C., 2018. Effect of Roads on Ecological Corridors Used for Wildlife Movement in a Natural Heritage Site. Sustainability 10. doi: $10.3390 /$ su10082725

Siyal, S. H., Mortberg, U., Mentis., D., Welsch, M., Babelon, I., Howells, M., 2015. Wind energy assessment considering geographic and environmental restrictions in Sweden: A GIS-based approach. Energy 83, 447-461. doi: 10.1016/j.energy.2015.02.044

Skarin, A., Nellemann, C., Ronnegard, L., Sandstrom, P., Lundqvist, H., 2015. Wind farm construction impacts reindeer migration and movement corridors. Landscape Ecology 30, 1527-1540. doi: 10.1007/s10980-015-0210-8

Stow, D., Petersen, A., Hope, A., Engstrom, R., Coulter, L., 2007. Greenness trends of Arctic tundra vegetation in the 1990s: Comparison of two NDVI datasets from NOAA AVHRR systems. International Journal of Remote Sensing 28, 4807-4822. doi: 10.1080/01431160701264284

Sun, S. P., Liu, F. L., Xue, S., Zeng, M., Zeng, F. X., 2015. Review on wind power development tin China: Current situation and improvement strategies to realize future development. Renewable and Sustainable Energy Reviews 45, 589-599. doi: 10.1016/j.rser.2015.02.018

Sun, R. H, Xie, W., Chen, L. D., 2018. A landscape connectivity model to quantify contributions of heat sources and sinks in urban regions. Landscape and Urban Planning 178, 43-50. doi: 10.1016/j.landurbplan.2018.05.015

Walker, R., Craighead, L., 1997. Analyzing wildlife movement corridors in Montana using GIS. 1997 ESRI International User Conference. In: gis.esri.com/library/userconf/proc97/proc97/to150/pap116/p116.htm.

Wang, C., Liu, S., Bie, Z. H., Wang, J. H., 2018. Renewable Energy Accommodation Capability Evaluation of Power System with Wind Power and Photovoltaic Integration. IFACPapersOnLine 51, 55-60. doi: 10.1016/j.ifacol.2018.11.677

Wang, S. F., Wang, S. C., Smith, P., 2015. Ecological impacts of wind farms on birds: Questions, hypotheses, and research needs. Renewable and Sustainable Energy Reviews 44, 599-607. doi: 10.1016/j.rser.2015.01.031

Wang, S. F., Wang, S., C., Liu, J., X., 2019. Life-cycle green-house gas emissions of onshore and offshore wind turbines. Journal of Cleaner Production 210, 804-810. doi: 10.1016/j.jclepro.2018.11.031

Wang, Y. H., 2011. Wind noise, light and shadow from the study of environmental protection. Northeastern University. (in Chinese)

Wasala, S. H., Storey R. C., Norris S. E., Cater J. E., 2015. Aeroacoustic noise prediction for wind turbines using large eddy simulation. Journal of Wind Engineering and Industrial Aerodynamics 145, 17-29. doi: 10.1016/j.jweia.2015.05.011

Wei, W., Li, P., Wang, H., Song, M., 2018. Quantifying the effects of air pollution control policies: A case of Shanxi province in China. Atmospheric Pollution Research 9, 429-438. doi: 10.1016/j.apr.2017.11.010 
Welcker, J., Nehls, G., 2016. Displacement of seabirds by an offshore wind farm in the North Sea. Marine Ecology Progress 554, 173-182. doi: 10.3354/meps11812

Wolsink, M., 2010. Near-shore wind power-Protected seascapes, environmentalists' attitudes, and the technocratic planning perspective. Land Use Policy 27, 195-203. doi: 10.1016/j.landusepol.2009.04.004

Yang, H., 2014. China must continue the momentum of green law. Nature 509, 535-535. doi: $10.1038 / 509535$ a

Yang, H., Clarke, J.L., Thompson, J.R. 2016. Nuclear energy: Improve collaboration. Science 353, 1107-1107. doi: 10.1126/science.aai8681

Yang, H.; Flower, R.J.; Thompson, J.R., 2012. Rural factories won't fix Chinese pollution. Nature 490, 342-343. doi: 10.1038/490342d

Yang, H., Flower, R.J., Thompson, J.R. 2013. China's new leaders offer green hope. Nature 493, 163-163. doi: 10.1038/493163d

Yang, H., Huang, X., Thompson, J.R., Flower, R.J. 2014a. Soil Pollution: Urban Brownfields. Science 344, 691-692. doi: 10.1126/science.344.6185.691-b

Yang, H.; Thompson, J.R.; Flower, R.J. 2014b. Earthshaking energy development plans. Science, 346, 710-711. doi: 10.1126/science.346.6210.710-b

Yang, H., Xia, J., Flower, R.J. 2017. Locals embrace China nuclear project. Nature 542 (7642), 414414. doi: $10.1038 / 542414 \mathrm{c}$

Yang, H., Xie, P., Ni, L., Flower R.J. 2012. Pollution in the Yangtze. Science 337, 410-410. doi: 10.1126/science.337.6093.410-a

Zeller, K. A., McGarigal, K., Whiteley, A. R., 2012. Estimating landscape resistance to movement: a review. Landscape Ecology 27, 777-797. doi: 10.1007/s10980-012-9737-0

Zhang, Y. R., 2016. The evaluation study of forest landscape pattern of Qinyuan County in Shanxi Province. Beijing forestry university. (in Chinese)

Zhao, H. R., Wu, Q. W., Hu, S. J., Xu, H. H., Rasmussen, C. N., 2015. Review of energy storage system for wind power integration support. Applied Energy 137, 545-553. doi: 10.1016/j.apenergy.2014.04.103

Zhao, W. J., Zhang, Y., Zhu, Q. K., Li, P., Yao, W. J., Ma, H., Bo, Y. J., 2014. Effects of Microtopography on Tree Growth Characteristics in Loess Slope of Northern Shaanxi. Journal of Basic Science and Engineering 22, 69-79. doi: 10.3969/j.issn.1005-0930.2014.01.008

Zhao, X., Tan, K., Zhao, S., Fang, J., 2011. Changing climate affects vegetation growth in the arid region of the northwestern China. Journal of Arid Environments 75, 946-952. doi: 10.1016/j.jaridenv.2011.05.007

Zhao, Z. Y., Yan, H., Zuo, J., Tian, Y. X., Zillante, G., 2013. A critical review of factors affecting the wind power generation industry in China. Renewable and Sustainable Energy Reviews 19, 499-508. doi: 10.1016/j.rser.2012.11.066

Zhou, W., Lou, C. Z., Li, Z. S., Lua, L., Yang, H. X., 2010. Current status of research on optimum sizing of stand-alone hybrid solar-wind power generation systems. Applied Energy 87, 380389. doi: 10.1016/j.apenergy.2009.08.012

Zhou, C., Huang, G., Chen, J., 2018. A Multi-Objective Energy and Environmental Systems Planning Model: Management of Uncertainties and Risks for Shanxi Province, China. Energies 11, 2723. doi: 10.3390/en11102723 

Ecologica Sinica 9, 2404-2412. doi: 10.3321/j.issn:1000-0933.2005.09.037 
821 Table 1 The relative resistance values of different landscape factors

\begin{tabular}{llllll}
\hline Factors & Classification & Value & Factors & Classification & Value \\
\hline The land use type & Forest & 1 & Vegetation coverage (\%) & $>75$ & 1 \\
& Grassland & 10 & & $60-75$ & 10 \\
& Farmland & 50 & & $45-60$ & 50 \\
& Construction land & 100 & & $30-45$ & 75 \\
Slope $\left(^{\circ}\right)$ & $<8$ & 1 & & $<30$ & 100 \\
& $8-15$ & 10 & NDVI residual & $<-0.05$ & 1 \\
& $15-25$ & 50 & & $-0.05-0.05$ & 50 \\
& $25-35$ & 75 & & $>0.05$ & 100 \\
Relief & $>35$ & 100 & & & 1 \\
& $<25$ & 1 & Distance from the turbine & $>500$ & 50 \\
& $25-50$ & 10 & $(\mathrm{~m})$ & $200-500$ & 100 \\
\hline
\end{tabular}

822

823 
Table 2 Statistical summary of NDVI variation trends

\begin{tabular}{cccccc}
\hline Variation trend & Serious degradation & Degradation & Unchanged & Increase & Significant increase \\
\hline Area $\left(\mathrm{m}^{2}\right)$ & 3.48 & 19.66 & 98.32 & 41.20 & 3.02 \\
Percent $(\%)$ & 2.10 & 11.87 & 59.35 & 24.87 & 1.82 \\
\hline
\end{tabular}

825

826 
Table 3 Land use categories

\begin{tabular}{lccc}
\hline \multirow{2}{*}{ Type } & \multicolumn{3}{c}{ Area $\left(\mathrm{km}^{2}\right)$} \\
\cline { 2 - 4 } & 2005 & 2017 & $\begin{array}{c}\text { Change between 2005 } \\
\text { and 2017 }\end{array}$ \\
\hline Evergreen needle forest & 25.92 & 27.21 & 1.30 \\
Deciduous broad-leaved forest & 78.11 & 86.74 & 8.63 \\
Deciduous broad-leaved shrub & 23.93 & 13.82 & -10.11 \\
Grass & 8.33 & 4.98 & -3.35 \\
Meadow & 23.54 & 18.20 & -5.34 \\
Farmland & 5.37 & 5.00 & -0.37 \\
Residence land & 0.45 & 0.41 & -0.03 \\
Wind power projects land & 0.00 & 9.27 & 9.27 \\
\hline
\end{tabular}

828

829 
Table 4 Landscape connectivity indices under different distance thresholds

\begin{tabular}{ccccc}
\hline \multirow{2}{*}{$\begin{array}{c}\text { Distance threshold } \\
(\mathrm{m})\end{array}$} & \multicolumn{2}{c}{ Without wind power project } & \multicolumn{2}{c}{ With wind power project } \\
\cline { 2 - 5 } & EC(IIC) & EC(PC) & EC(IIC) & EC(PC) \\
\hline 1000 & 19.41 & 22.51 & 14.54 & 20.02 \\
3000 & 22.41 & 24.02 & 22.22 & 23.08 \\
5000 & 22.41 & 24.29 & 22.41 & 23.72 \\
\hline
\end{tabular}

831

832 
Table 5 Comparison between this study with previous studies

\begin{tabular}{|c|c|c|c|}
\hline Objective & Methods & Results & Data sources \\
\hline $\begin{array}{l}\text { Eagles and other } \\
\text { raptors along } \\
\text { migratory routes }\end{array}$ & GPS-data & $\begin{array}{l}\text { The frequency of collisions or } \\
\text { displacement of raptors away from their } \\
\text { usual migratory pathways increased as } \\
\text { wind energy projects grow. }\end{array}$ & Katzner et al., 2012 \\
\hline $\begin{array}{l}\text { Distribution of } \\
\text { migratory bird } \\
\text { stopovers }\end{array}$ & $\begin{array}{l}\text { Migratory } \\
\text { concentration } \\
\text { models }\end{array}$ & $\begin{array}{l}73 \% \text { of high potential wind development } \\
\text { area intersects the important bird } \\
\text { migration concentration areas in } \\
\text { Wyoming. }\end{array}$ & Pocewicz et al., 2013 \\
\hline $\begin{array}{l}\text { Landscape } \\
\text { connectivity for } \\
\text { bats }\end{array}$ & $\begin{array}{l}\text { Species } \\
\text { Distribution } \\
\text { Model }\end{array}$ & $\begin{array}{l}54 \% \text { of the existing and } 72 \% \text { of planned } \\
\text { wind farms interfere with important } \\
\text { corridors connecting western and eastern } \\
\text { parts of the study areas. }\end{array}$ & Roscioni et al., 2014 \\
\hline $\begin{array}{l}\text { Reindeer migration } \\
\text { and movement } \\
\text { corridors }\end{array}$ & GPS-data & $\begin{array}{l}\text { During construction of the wind farms, } \\
\text { use of original migration routes and } \\
\text { movement corridors declined by } 76 \% \text {. }\end{array}$ & Skarin et al., 2015 \\
\hline $\begin{array}{l}\text { Migratory bald } \\
\text { eagles }\end{array}$ & $\begin{array}{l}\text { Dynamic } \\
\text { Brownian bridge } \\
\text { movement model }\end{array}$ & $\begin{array}{l}\text { There was small overlap between bald } \\
\text { eagle migration corridors and viable wind } \\
\text { power areas in northeastern North } \\
\text { America. }\end{array}$ & Mojica et al., 2016 \\
\hline Migratory raptor & $\begin{array}{l}\text { Radar and hawk- } \\
\text { watch monitoring } \\
\text { observations }\end{array}$ & $\begin{array}{l}\text { Migratory raptors adjusted their flight } \\
\text { trajectories to avoid wind farms. }\end{array}$ & $\begin{array}{l}\text { Cabrera-Cruz et al., } \\
2016\end{array}$ \\
\hline $\begin{array}{l}\text { Habitat selection } \\
\text { by wintering geese }\end{array}$ & Linear models & $\begin{array}{l}\text { Geese strongly avoided power-lines, and } \\
\text { wind turbines. }\end{array}$ & Harrison et al., 2017 \\
\hline $\begin{array}{l}\text { Migration corridor } \\
\text { of white storks }\end{array}$ & $\begin{array}{l}\text { Multi-criterial } \\
\text { evaluation model }\end{array}$ & $\begin{array}{l}\text { Approximately } 60 \% \text { of the patches in the } \\
\text { predicted migration corridor had either a } \\
\text { moderate or high potential for wind } \\
\text { energy generation. }\end{array}$ & Francis et al., 2018 \\
\hline $\begin{array}{l}\text { Ecological corridor } \\
\text { and landscape } \\
\text { connectivity }\end{array}$ & LCD and LCP & $\begin{array}{l}\text { Wind power projects reduced corridor } \\
\text { patency, lengthened most of corridors, and } \\
\text { weakened landscape connectivity. }\end{array}$ & This study \\
\hline
\end{tabular}




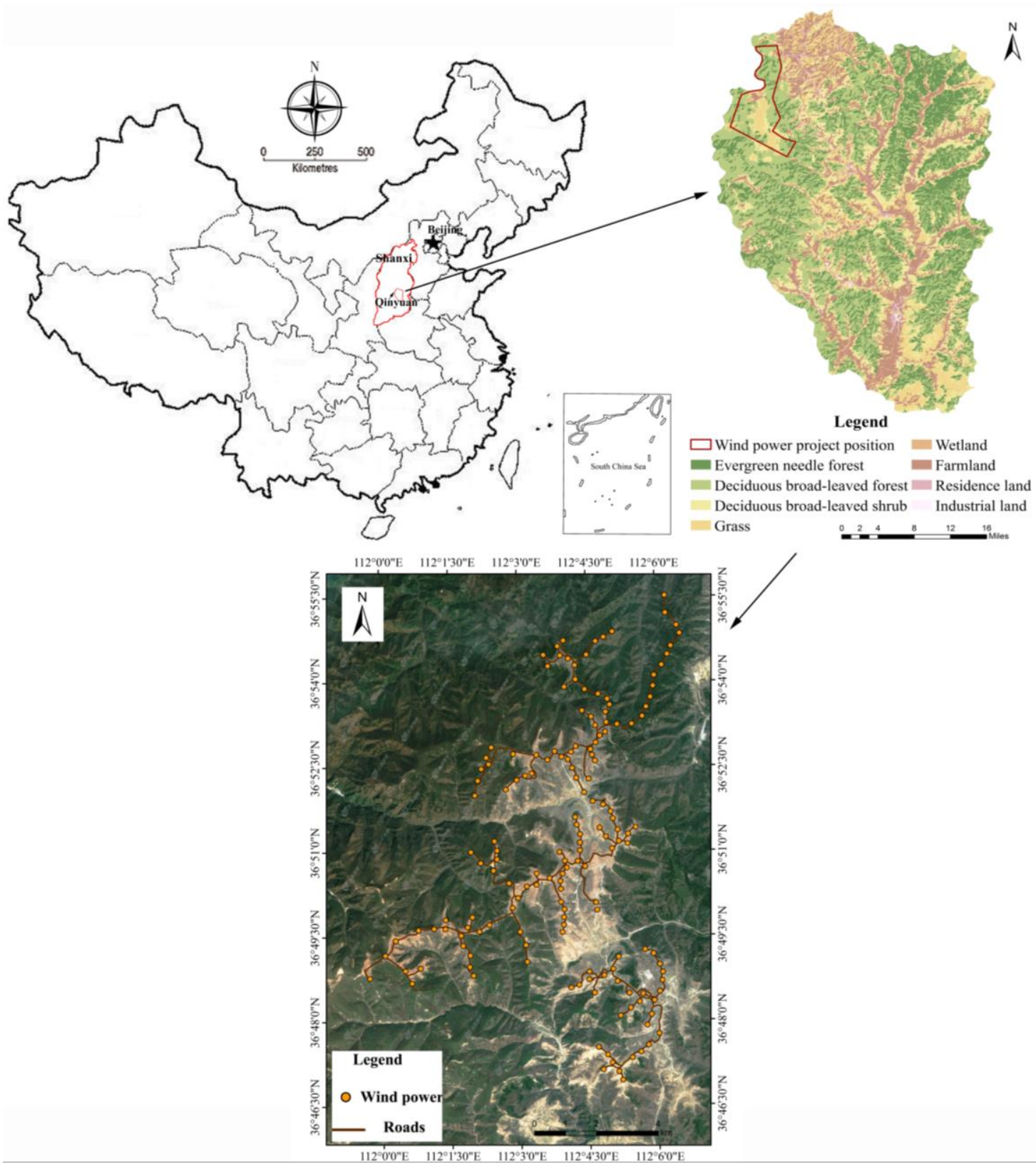




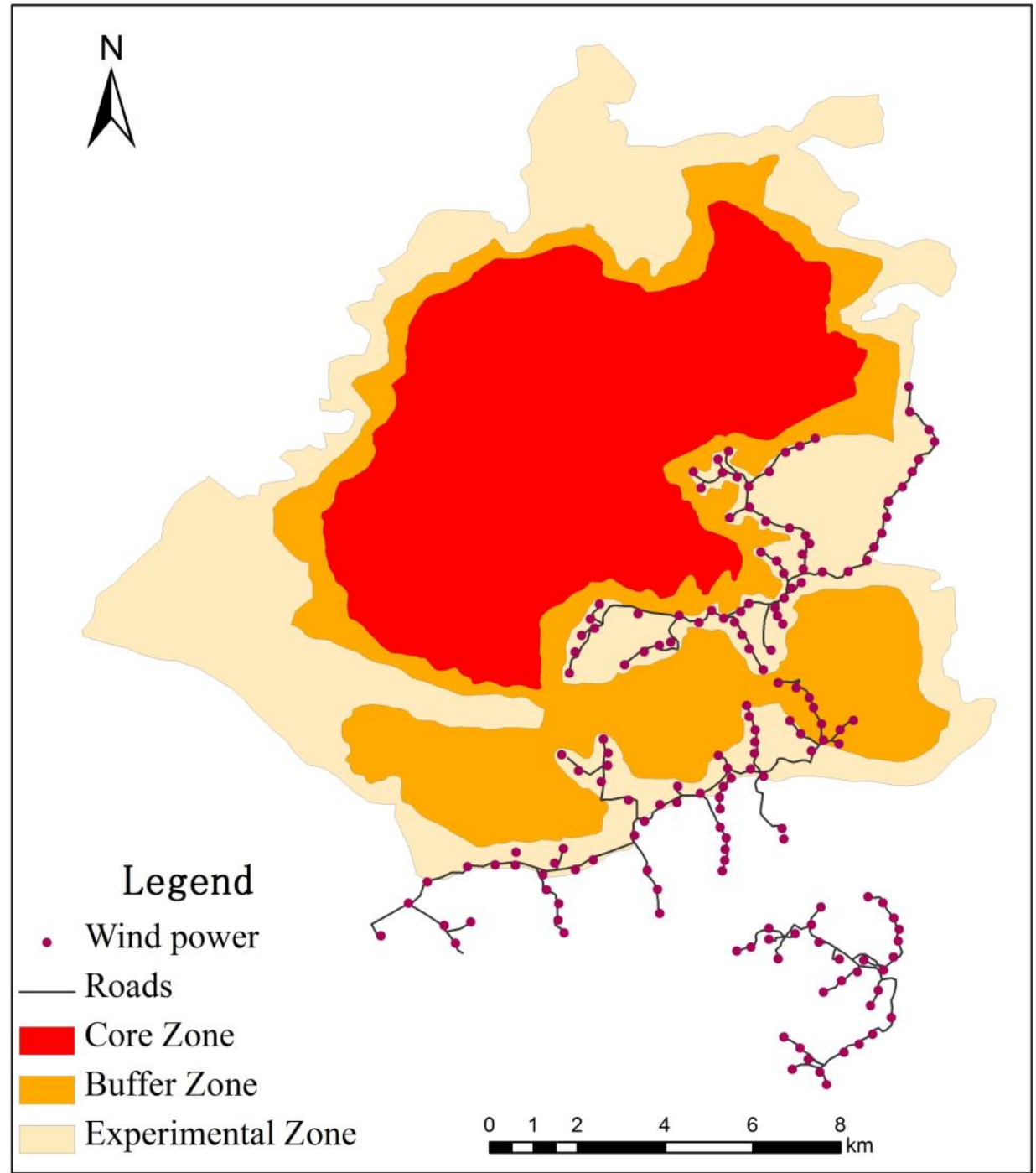

Fig.2. Wind power project, the road, and core, buffer and experimental zones of Mianshan Nature Reserve in the study area. 


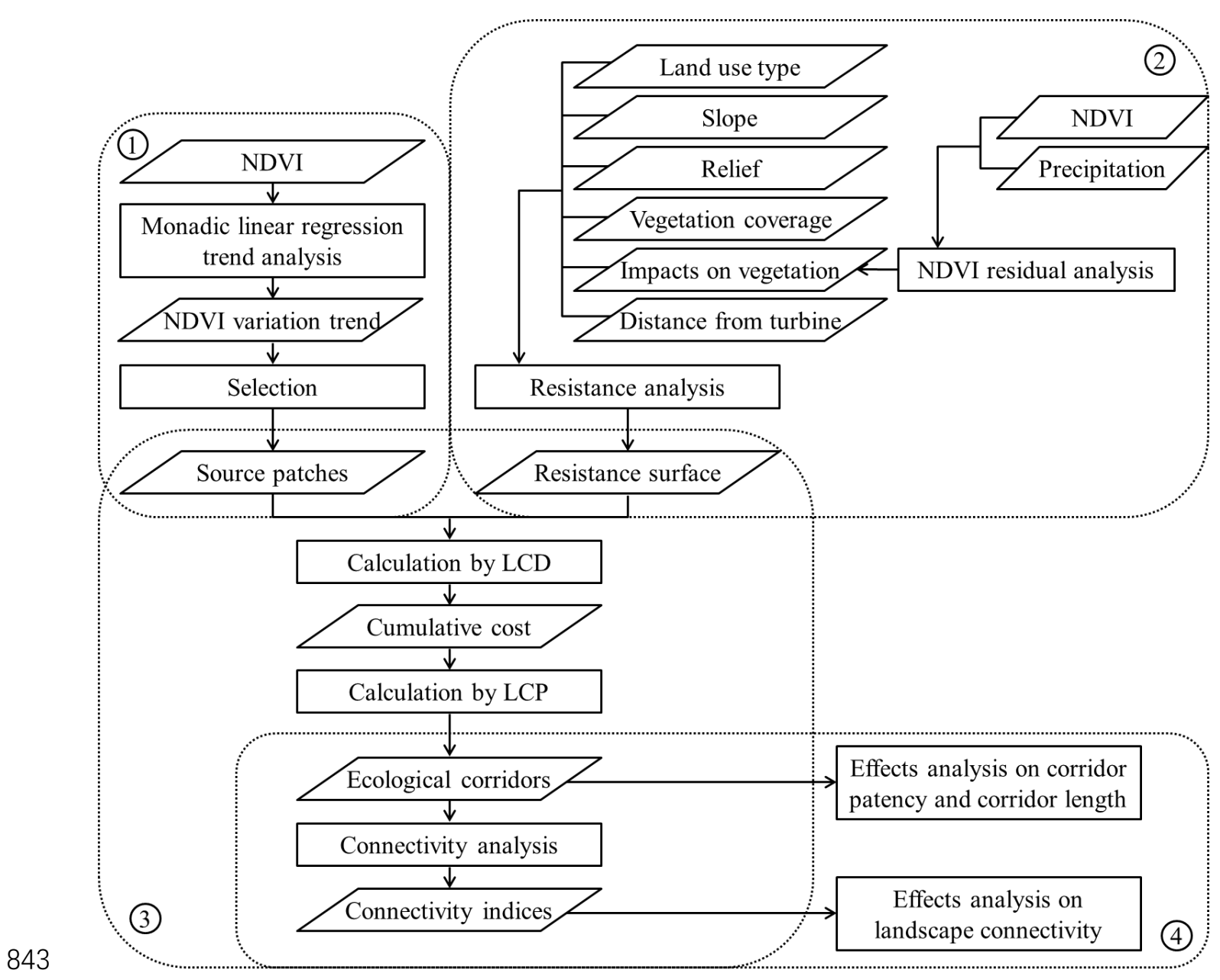

Fig. 3. Methodology of the study.

Note: Rhombuses represent data sources or products, and rectangles represent processes or methods. 


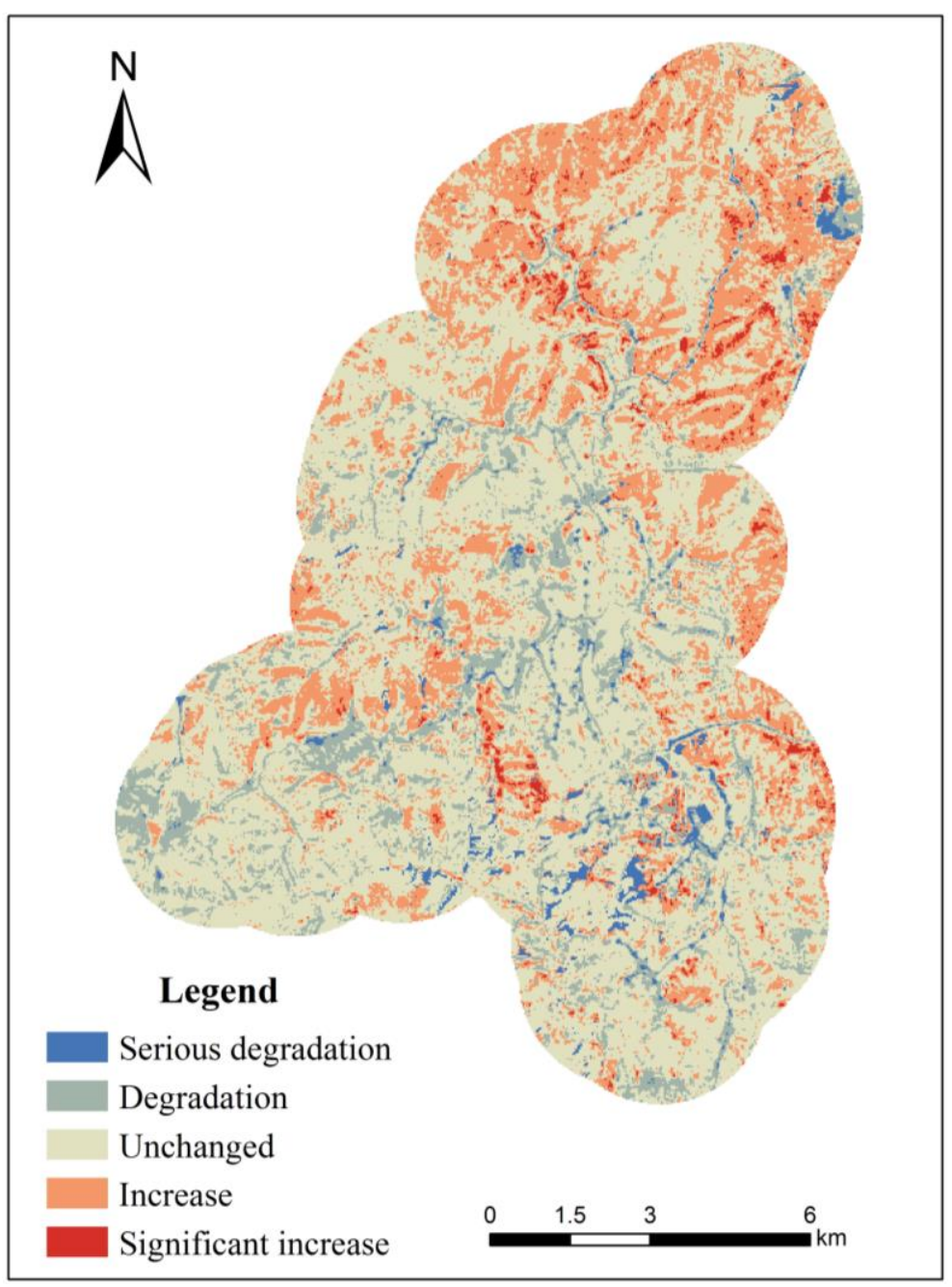

Fig.4. The spatial distribution of the change rates of pixel's NDVI. 


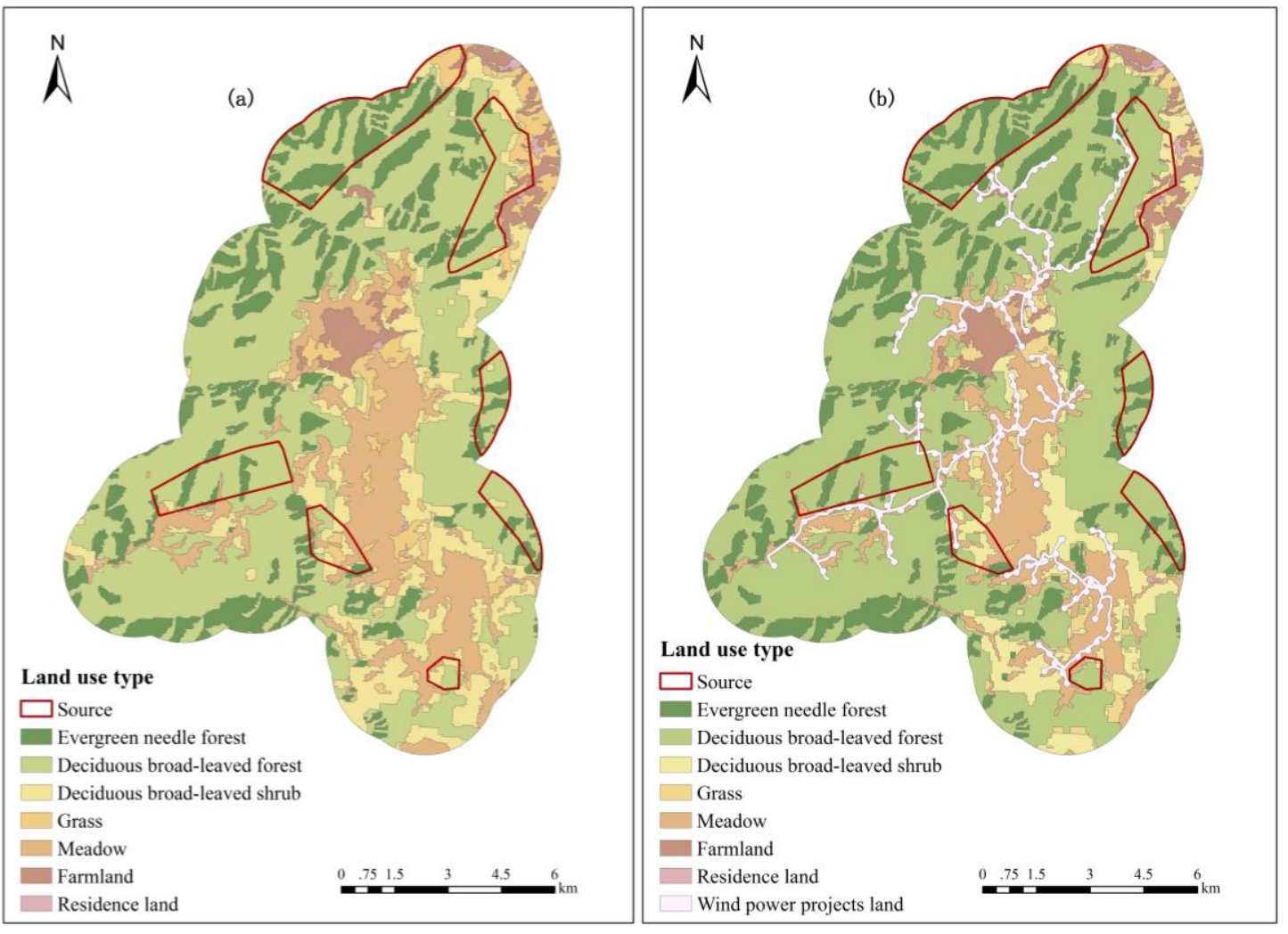

850

Fig.5. Land use categories: (a) without the wind power projects; and (b) with the wind power projects. 


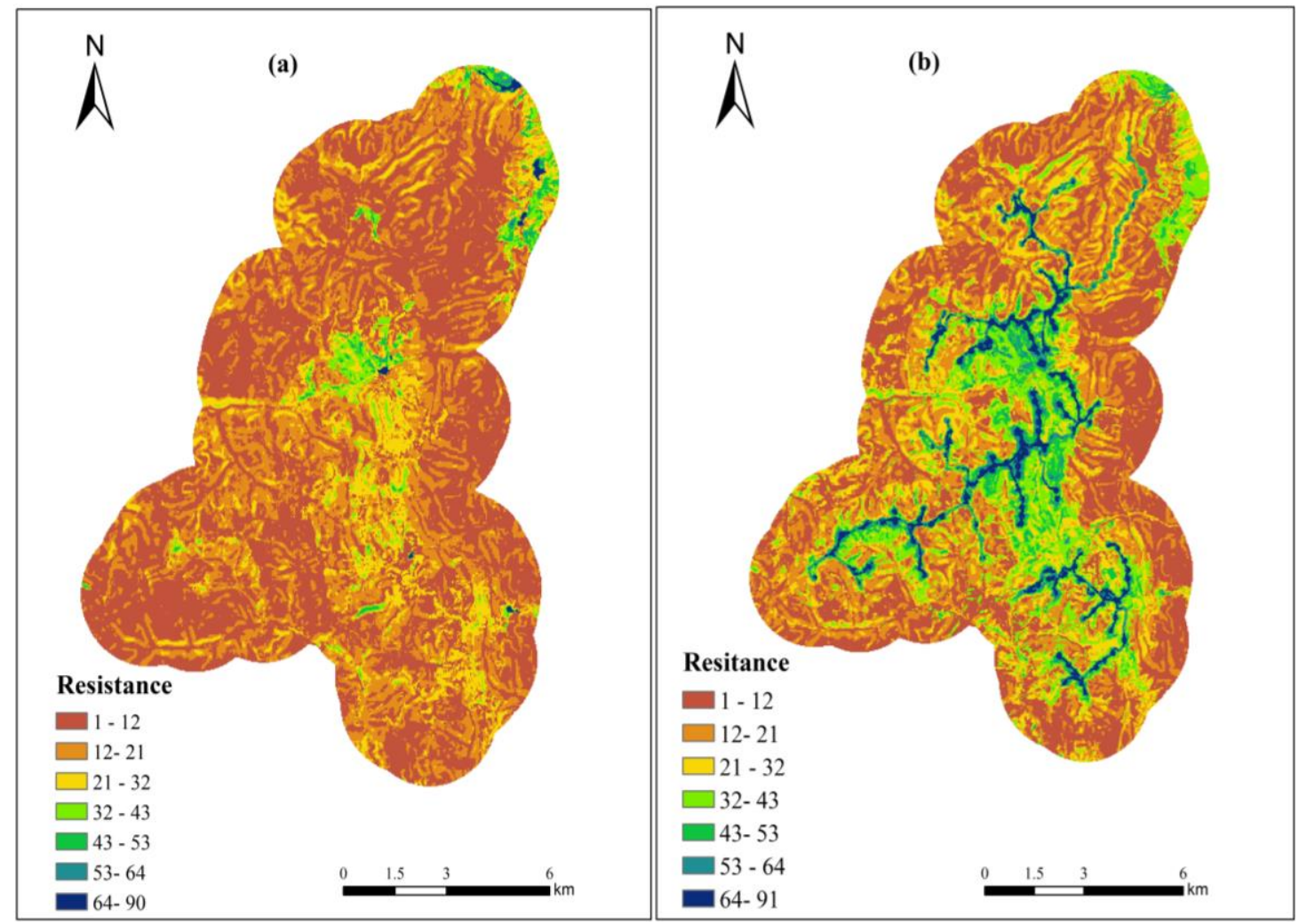

Fig.6. The spatial distribution of resistance: (a) without the wind power project; and (b) with the wind power 854 project. 

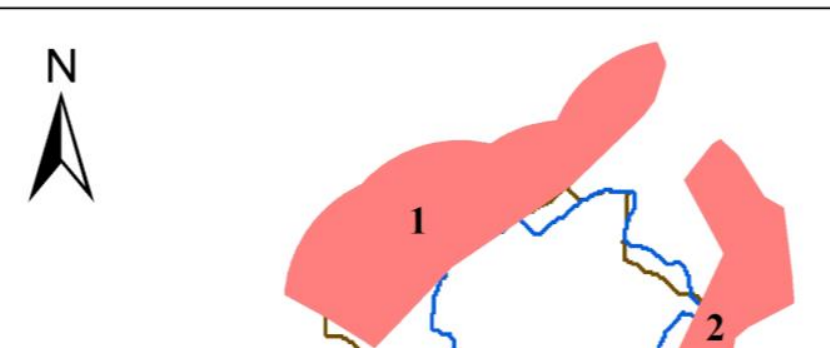

\section{Legend}

Source

Without wind power project

With wind power project

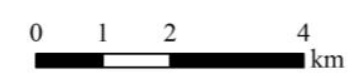

Fig.7. Potential ecological corridors with and without the wind power projects. Note: Numbers 1-7 represents different sources.

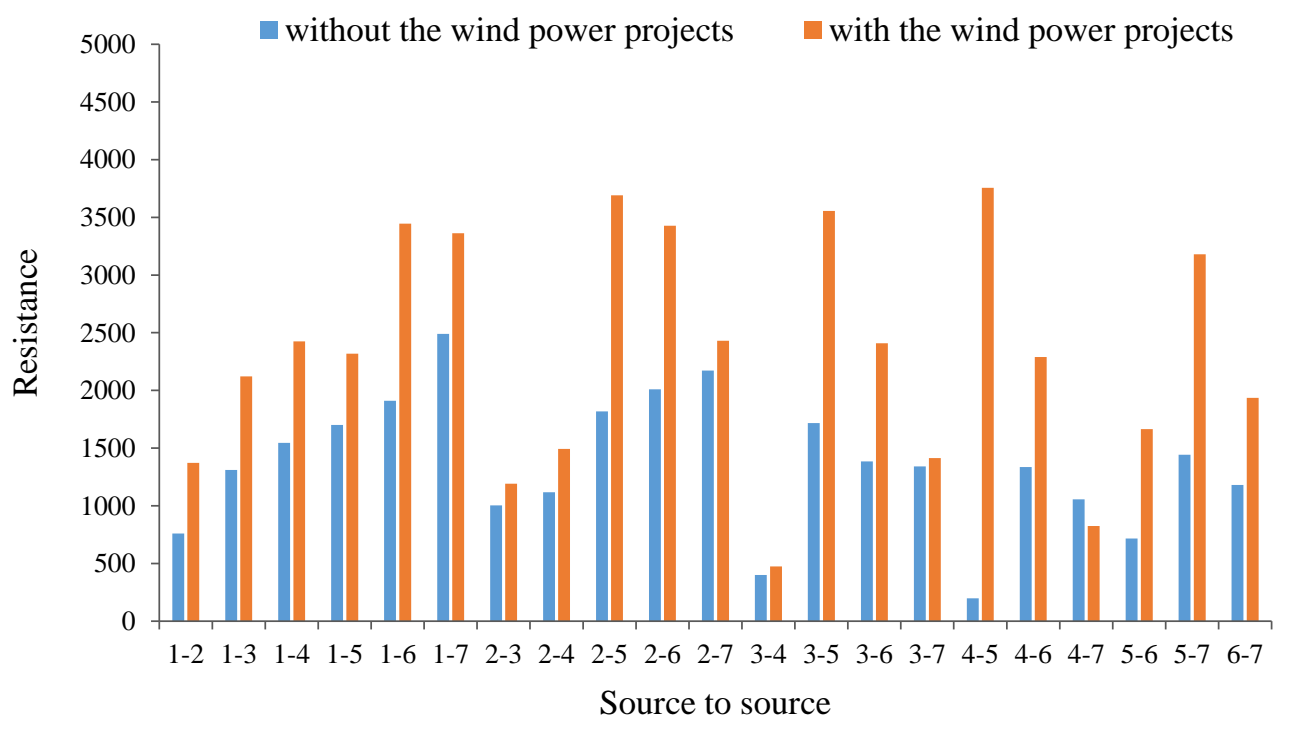


Fig.8. The impact of the wind power project on corridor patency. 


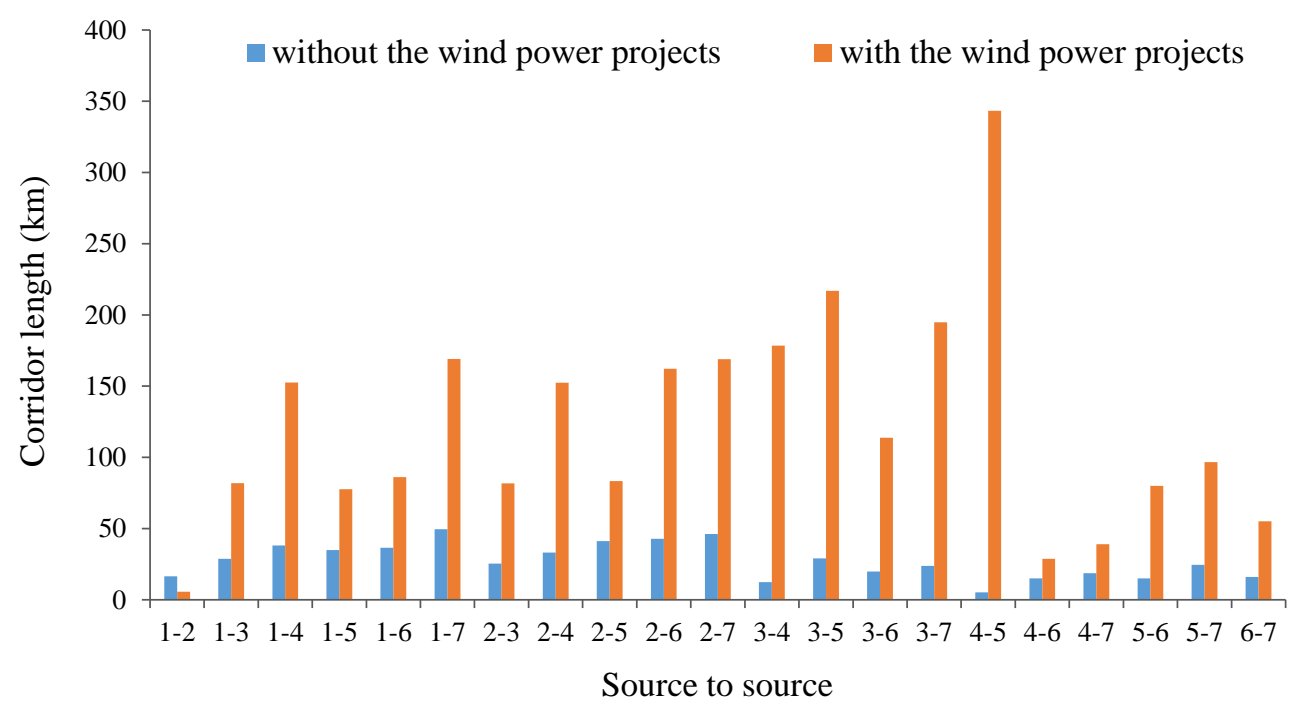

Fig.9. The impact of the wind power project on corridor length. 